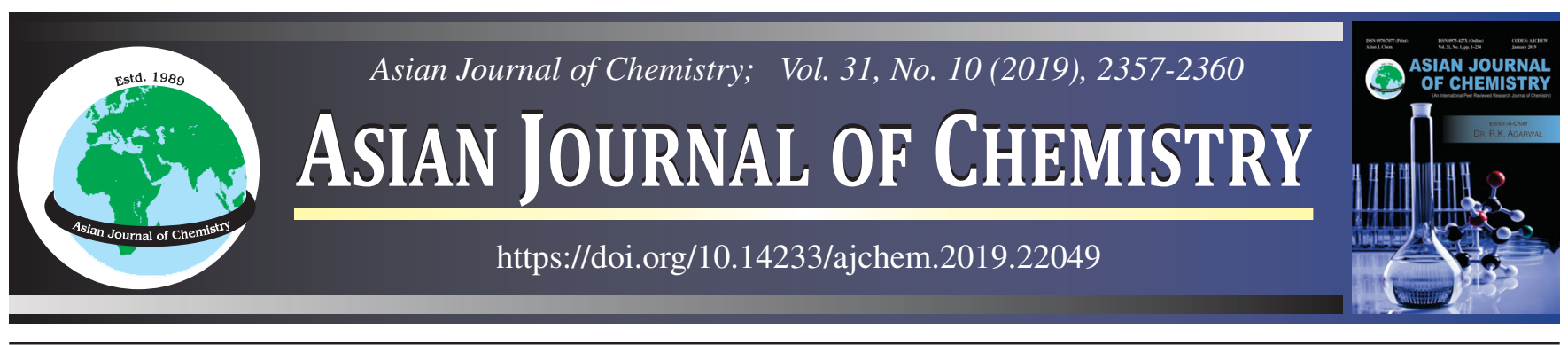

\title{
Synthesis and Spectral Studies of Some Bioactive Transition Metal Complexes of [bis-2-(4-Fluorophenyl)prop-2-enaln]ethane-1,2-diamine
}

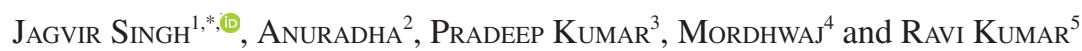

${ }^{1}$ Department of Chemistry, Atma Ram Sanatan Dharma College (University of Delhi), New Delhi-110021, India

${ }^{2}$ Department of Zoology, Raghuveer Singh Government P.G. College, Lalitpur-284403, India

${ }^{3}$ Department of Chemistry, D.A.V. (P.G.) College, Budhana-251309, India

${ }^{4}$ Center of Biomedical Research (ACBR), North Campus, University of Delhi, New Delhi-110007, India

${ }^{5}$ Department of Chemistry, Om Parkash Jogender Singh University, Churu-331303, India

*Corresponding author: Tel/Fax: +91 11 24113436; E-mail: singhjagvir0143@gmail.com

Received: 15 March 2019;

Accepted: 27 June 2019;

Published online: 30 August 2019;

AJC-19551

$\mathrm{Co}(\mathrm{II}), \mathrm{Ni}(\mathrm{II})$ and $\mathrm{Cu}(\mathrm{II})$ metal complexes of a novel Schiff base ligand (SBL) derived from condensation of 2-(4-fluorophenyl)prop-2enaln and ethane-1,2-diamine were synthesized. All the complexes were characterized by elemental analyses, IR, UV-visible spectroscopy, magnetic susceptibility and conductance measurements and ${ }^{1} \mathrm{H}$ NMR. From the elemental analysis data, 1:1 [M]:[ligand] metal chloride complexes are formed having the general composition $\left[\mathrm{M}(\mathrm{SBL}) \mathrm{Cl}_{2}\right]$ and $[\mathrm{Cu}(\mathrm{SBL})] \mathrm{Cl}_{2}$, [where $\mathrm{M}=\mathrm{Co}(\mathrm{II}), \mathrm{Ni}(\mathrm{II})$ and $\mathrm{SBL}=\{$ bis-2-(4-

fluorophenyl)prop-2-enaln \}ethane-1,2-diamine]. The result showed that the ligand is coordinated to the metal ions in a neutral tetradentate manner with $\mathrm{ON}$ donor sites and the nature of metal-ligand bonding can range from covalent to ionic. Antimicrobial activities of the newly synthesized chemical compounds were evaluated against Staphylococcus aureus (ATCC 25923), Staphylococcus aureus (ATCC 3160), Cabdida albicans (ATCC 227) and Staphylococcus cereviscae (ATCC 361) species and found that metal complexes exhibited more antimicrobial properties so they are more potential and significant than the ligand.

Keywords: Schiff base ligands, Metal complexes, Spectral study, Biological study.

\section{INTRODUCTION}

The Schiff base ligands can be synthesized by the condensation of aldehydes and ketones with amines and they can also be used for the synthesis of metal complexes in the coordination chemistry [1,2]. Enhancement in biological activity and decrease in cytotoxic effects on the host are achieved by incorporating metal ions into the Schiff base ligands [3-5].

The reactions of Schiff bases have obtained prime importance in organic chemistry because these reactions are utilized as a suitable route for making $\mathrm{C}-\mathrm{N}$ bonds [6-8]. The significance of such bonds can be considered by its use in biological systems for transamination and elucidation of racemization mechanisms. Besides these facts, this bond is considered responsible for various biological activities, such as antimicrobial, anticonvulsant, anti-inflammatory, antitumor, herbicidal, antituberculosis and anti-HIV activities [9,10].
The Schiff base ligand molecules containing nitrogen, oxygen, halogens etc. as donar sites have been used for the preparation of the metal complexes [11]. These Schiff bases containing halogen groups and their metal complexes have a special interest due to their antimicrobial properties. A great deal of attention in this area has been focused on the complexes formed by transition metal ions with Schiff bases because of the presence of both nitrogen and oxygen donor atoms in the backbones of such type ligands [12-16].

Recently much interest has been paid by inorganic chemists in the study of metal chelates having only oxygen-nitrogen containing ligands due to their importance as fungicides, pesticides, catalyst, enzymatic reaction, magnetism, molecular architecture and high pressure lubricants [17-22]. It is also reported that Schiff base ligands, with one or more halo-atoms in the aromatic ring, shows biological activities like antitumor, antibacterial and antifungal activities [23]. Steric and electronic

This is an open access journal, and articles are distributed under the terms of the Attribution 4.0 International (CC BY 4.0) License. This license lets others distribute, remix, tweak, and build upon your work, even commercially, as long as they credit the author for the original creation. You must give appropriate credit, provide a link to the license, and indicate if changes were made. 
effects of substituent's in the coordination zone increases the activity of the metal and the other groups on ligands that not attended to coordination may also have an impact on this activity [24].

Such type of ligands and their metal complexes are used in many catalytic reactions. The copper, nickel and cobalt metal complexes are very active and selective hydrogen transfer catalysts. Such metal complexes play an important role in the development of the organometallic branch and have also proved to be very helpful to understand their structure. In this manuscript we are reporting the synthesis of the $\mathrm{Co}$ (II), $\mathrm{Ni}$ (II) and $\mathrm{Cu}$ (II) metal complexes with newly prepared Schiff base ligand. In this study we choose bis-2-(4-fluorophenyl)prop-2-enaln \}ethane-1,2-diamine ligand which contains nitrogen-oxygen atoms, imine group, halogens at aromatic ring are responsible for antimicrobial activities and some other properties. All the newly synthesized compounds were well characterized by different spectroscopic techniques. Their biological behaviour against different microbial species are also studied.

\section{EXPERIMENTAL}

All the chemical e.g. 2-(4-fluorophenyl)prop-2-enaln, ethane-1,2-diamine, metal salts and solvents (Qualigens Chemicals Company) were A.R. grade. Open capillary method were used for detection of melting points. Carlo-Erba 1106 Elemental Analyzer was used for the elemental analysis. Shimadzu-160 FT/IR spectrophotometer was use to record IR Spectra of newly synthesized compounds. ${ }^{1} \mathrm{H}$ NMR spectra (Bruker DPX-400) obtained by using tetramethylsilane (internal standard).

Synthesis of ligand: In a round bottom flask, 2-(4-fluorophenyl)prop-2-enaln $(3.2 \mathrm{~mL}, 0.02 \mathrm{mmol})$ in methanol (15 $\mathrm{mL})$ was drop wise added to a $5 \%$ acetic acid $(0.32 \mathrm{~g}, 0.01$ $\mathrm{mmol})$ in water $(20 \mathrm{~mL})$ and ethane-1,2-diamine $(0.60 \mathrm{~g}, 0.01$ $\mathrm{mmol}$ ) in methanol $(15 \mathrm{~mL}$ ) solution (Scheme-I). The mixture was refluxed about $2 \mathrm{~h}$ at $80{ }^{\circ} \mathrm{C}$ to obtain Schiff base ligand (SBL). Now precipitate was repeatedly washed with ethanol and diethyl ether.

Synthesis of metal complexes: The Schiff base ligand (SBL) was mixed with an equal proportion of metal chlorides salts $[(\mathrm{Co}$ (II) $\mathrm{Ni}(\mathrm{II})$ and $\mathrm{Cu}(\mathrm{II})](1.0 \mathrm{mmol})$ in ethanol $(1: 1$, $25 \mathrm{~mL}$ ). The reaction mixture was refluxed for $2 \mathrm{~h}$ at $70{ }^{\circ} \mathrm{C}$. The reaction progression was monitored by TLC with a solvent system containing ethyl acetate and cyclohexane (1:3) (Scheme-II).

Ligand (SBL): Yield: $90 \%$; m.p. $240{ }^{\circ} \mathrm{C}$, m.w. 356, colour: yellow; analytical data for $\mathrm{C}_{20} \mathrm{H}_{18} \mathrm{~F}_{2} \mathrm{~N}_{2} \mathrm{O}_{2}$ found (calc.): C, 67.05 (68.99); H, 5.06 (5.46); F 10.43, (10.91); N, 7.42 (7.97). IR (KBr, cm$\left.{ }^{-1}\right): 1660 v(\mathrm{C}-\mathrm{NH}), 1690 v(\mathrm{C}=\mathrm{O})$. ESIMS, $m / z$ Data found (calc.): 241 (240), ${ }^{1} \mathrm{H}$ NMR (DMSO- $d_{6}$ ) $\delta$ ppm: 7.1 (m, 8H, HC-Ar), 3.8 (s, 2H, NH-).

Cobalt(II) complex: Yield: $68 \%$; m.p.: $395{ }^{\circ} \mathrm{C}$; m.w. 389 ; colour: pinkish; analytical data for $\left[\mathrm{Co}\left(\mathrm{C}_{18} \mathrm{H}_{16} \mathrm{~F}_{2} \mathrm{~N}_{2} \mathrm{O}_{2}\right) \mathrm{Cl}_{2}\right]$ found (calc.): C, 55.54 (55.15); H, 4.14 (3.95); N, 7.20 (7.19); IR $\left(\mathrm{KBr}, \mathrm{cm}^{-1}\right): 3412 \mathrm{v}(\mathrm{NH}), 1610 \mathrm{v}(\mathrm{N}=\mathrm{CH}), 3015 \mathrm{v}(\mathrm{C}-\mathrm{H})$, $2220 v(\mathrm{C}-\mathrm{N}), 570 v(\mathrm{M}-\mathrm{N}), 410 v(\mathrm{M}-\mathrm{Cl})$.

Nickel(II) complex: Yield: $88 \%$; m.p.: $385^{\circ} \mathrm{C}$; m.w. 388; colour: dark greenish; analytical data for $\left[\mathrm{Ni}\left(\mathrm{C}_{18} \mathrm{H}_{16} \mathrm{~F}_{2} \mathrm{~N}_{2} \mathrm{O}_{2}\right)\right] \mathrm{Cl}_{2}$ found (calc.): C, 55.57 (55.15), H, 4.16 (4.11), N, 7.20 (7.41). IR $\left(\mathrm{KBr}, \mathrm{cm}^{-1}\right): 3402 \mathrm{v}(\mathrm{NH}), 1609 \mathrm{v}(\mathrm{N}=\mathrm{CH}), 3015 \mathrm{v}(\mathrm{C}-\mathrm{H})$, $2210 v(\mathrm{C}-\mathrm{N}), 579 \mathrm{v}(\mathrm{M}-\mathrm{N}), 411 \mathrm{v}(\mathrm{M}-\mathrm{Cl})$.

Copper(II) complex: Yield: $65 \%$; m.p.: $360{ }^{\circ} \mathrm{C}$; m.w. 393 ; colour: dark bluish; analytical data for $\left[\mathrm{Cu}\left(\mathrm{C}_{18} \mathrm{H}_{16} \mathrm{~F}_{2} \mathrm{~N}_{2} \mathrm{O}_{2}\right)\right] \mathrm{Cl}_{2}$ found (calc.): C, 54.89 (54.15), H, 4.09 (4.01), N, 7.11 (7.07). IR $\left(\mathrm{KBr}, \mathrm{cm}^{-1}\right): 3402 \mathrm{v}(\mathrm{NH}), 1615 \mathrm{v}(\mathrm{N}=\mathrm{CH}), 3015 \mathrm{v}(\mathrm{C}-\mathrm{H})$, $2210 v(\mathrm{C}-\mathrm{N}), 530 v(\mathrm{M}-\mathrm{N}), 430 \mathrm{v}(\mathrm{M}-\mathrm{Cl})$.
2.<smiles>O=C/C=C/c1ccc(F)cc1O</smiles><smiles>NCCN</smiles><smiles>CN=C/C=C\c1ccc(F)cc1O</smiles><smiles>CC/N=C\C=C/c1ccc(F)cc1O</smiles>

Scheme-I: Synthesis of Schiff base ligand (SBL)
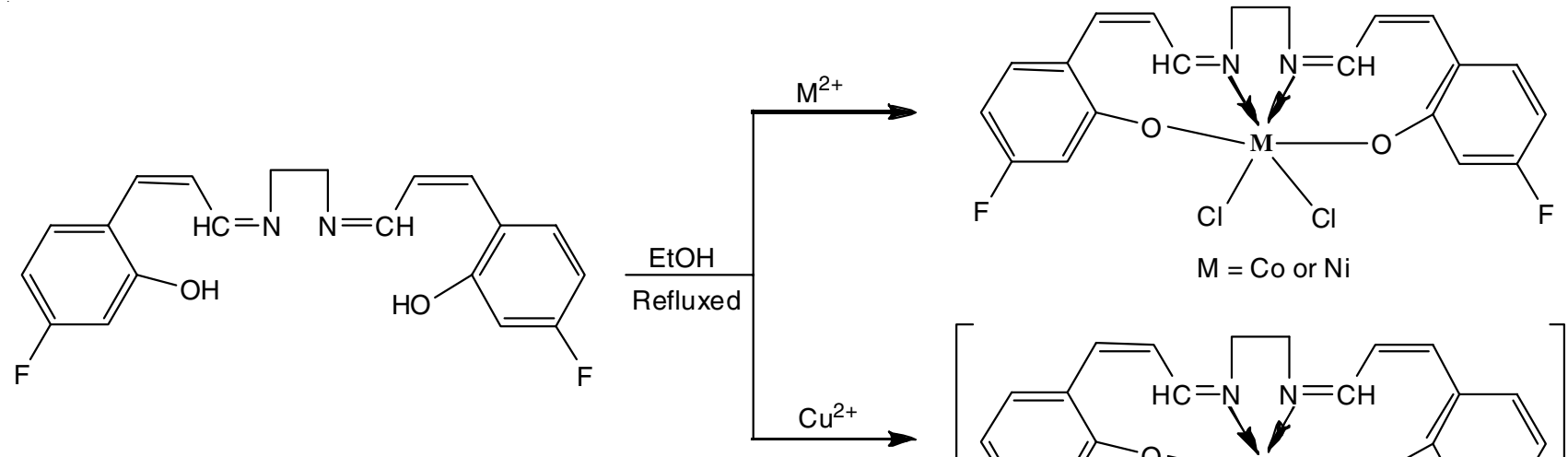

$\mathrm{M}=\mathrm{Co}$ or $\mathrm{Ni}$

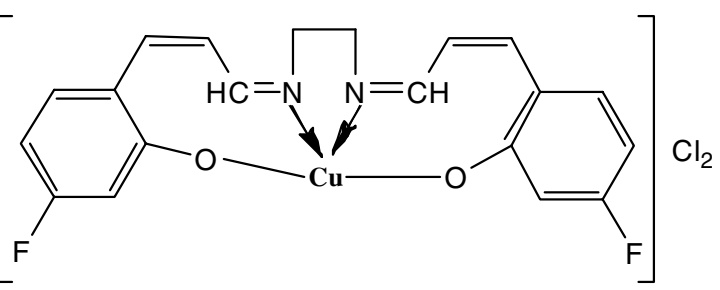

Scheme-II: Route of synthesis of metal complexes 


\section{RESULTS AND DISCUSSION}

The IR spectra of newly synthesized compound were recorded in (v) 4000-400 $\mathrm{cm}^{-1}$ region. At $1660 \mathrm{~cm}^{-1}$ a band which indicate the presence of carbonyl stretching of 2-(4fluorophenyl)prop-2-enaln. At $1610 \mathrm{~cm}^{-1}$ showed peak indicated the presence of azomethine group of SBL [26-28]. In the spectra of metal complexes showed moderate change in this azomethine frequency. In metal complexes IR spectra showed band at $480-445$ and $579-530 \mathrm{~cm}^{-1}$ indicated to (M-N) and (M-O) respectively [29].

The ${ }^{1} \mathrm{H}$ NMR of SBL showed a singlet signal at $\delta 11.34$ ppm which indicated the phenolic -OH group. In the spectra of metal complexes this peak was absent which was confirming the formation of M-O bonding. Spectra of Schiff base ligand showed sharp singlet peak at $\delta 8.15$ indicated the presence of azomithine group [30]. Due to interaction of $\mathrm{N}$-atom of azomithine and metal ions in all complexes showed sharp singlet peaks at $\delta 8.10-8.14 \mathrm{ppm}$.

$\mathrm{UV} / \mathrm{Vis}$ spectrophotometer at concentration $\left(10^{-5} \mathrm{M}\right.$ in ethanol) was used to determine the $\lambda_{\max }$ of all the newly synthesize compounds and recorded as Table-1. The electronic spectra of the cobalt(II) complex showed three bands at 8810, 17775 and $30270 \mathrm{~cm}^{-1}$, which may be assigned to ${ }^{4} \mathrm{~T}_{1 \mathrm{~g}} \rightarrow{ }^{4} \mathrm{~T}_{2 \mathrm{~g}}(\mathrm{~F}){ }^{4} \mathrm{~T}_{1 \mathrm{~g}}$ $\rightarrow{ }^{4} \mathrm{~T}_{1 \mathrm{~g}}(\mathrm{P})$ and ${ }^{4} \mathrm{~T}_{1 \mathrm{~g}} \rightarrow{ }^{3} \mathrm{~A}_{2 \mathrm{~g}}(\mathrm{~F})$ transitions and suggested octahedral geometry $[31,32]$ around the cobalt ion.

\begin{tabular}{ccc}
\multicolumn{3}{c}{ TABLE-1 } \\
& $\begin{array}{c}\text { ELECTRONIC SPECTRAL DATA (nm) } \\
\text { OF THE METAL COMPLEXES }\end{array}$ \\
\hline Complexes & \multicolumn{1}{c}{$\lambda_{\max }(\mathrm{nm})$} & Assignments \\
\hline$\left[\mathrm{Co}(\mathrm{SBL}) \mathrm{Cl}_{2}\right]$ & $211,283,333,399,457,643$ & $\mathrm{n}-\pi^{*}, \pi-\pi^{*}, \mathrm{~d}-\mathrm{d}$ \\
{$\left[\mathrm{Cu}(\mathrm{SBL}) \mathrm{Cl}_{2}\right]$} & $236,275,335,366,425,580$ & $\mathrm{n}-\pi^{*}, \pi-\pi^{*}, \mathrm{~d}-\mathrm{d}$ \\
{$\left[\mathrm{Ni}(\mathrm{SBL}) \mathrm{Cl}_{2}\right]$} & $270,330,350,375,610$ & $\mathrm{n}-\pi^{*}, \pi-\pi^{*}, \mathrm{~d}-\mathrm{d}$ \\
\hline
\end{tabular}

The electronic spectra of the copper(II) complex displays a broad band at $14918 \mathrm{~cm}^{-1}$ due to ${ }^{2} \mathrm{~B}_{1 \mathrm{~g}} \rightarrow{ }^{2} \mathrm{E}_{\mathrm{g}}$ and two bands at 16550 and $27350 \mathrm{~cm}^{-1}$ assigned to $d-d$ transitions and a charge transfer band respectively, of square planner environment. The nickel(II) complex exhibited three bands 10565, 17155 and $29985 \mathrm{~cm}^{-1}$ assignable to the transitions ${ }^{3} \mathrm{~A}_{2 \mathrm{~g}}(\mathrm{~F}) \rightarrow{ }^{3} \mathrm{~T}_{2 \mathrm{~g}}(\mathrm{~F})$ $\left(v_{1}\right),{ }^{3} \mathrm{~A}_{2 \mathrm{~g}}(\mathrm{~F}) \rightarrow{ }^{3} \mathrm{~T}_{1 \mathrm{~g}}(\mathrm{~F})\left(\mathrm{v}_{2}\right)$ and ${ }^{3} \mathrm{~A}_{2 \mathrm{~g}}(\mathrm{~F}) \rightarrow{ }^{3} \mathrm{~T}_{1 \mathrm{~g}}(\mathrm{P})\left(\mathrm{v}_{3}\right)$, respec- tively which are characteristic of nickel(II) in octahedral geometry [33].

The magnetic moment of cobalt, nickel and copper complex were 5.08, 2.90 B.M. while for copper complex the magnetic moment value is 1.75 B.M. The value suggested the octahedral geometry for $\mathrm{Co}$ and $\mathrm{Ni}$ complexes while for $\mathrm{Cu}$ square planar geometry [34-36]. The Ni(II) and $\mathrm{Co}(\mathrm{II})$ complexes are nonelectrolytic and $\mathrm{Cu}$ (II) complex is electrolyte in nature by their molar conductivity $\left(\Lambda_{\mathrm{m}}\right)$ as measured in DMSO.

Biological activity: Antimicrobial activities were studied by an agar well diffusion method using Nutrient Agar and Sabouraud Dextrose Agar media for bacterial and fungal pathogens, respectively [37-40]. Antimicrobial diffusion assays were performed using cell suspensions containing $1.5 \times 10^{6}$ CFU/mL employing the McFarland turbidity standard No. 0.5. To determine the MIC, first we prepared Stock solutions and dissolve the newly synthesized compounds in DMF (100 mg/ $\mathrm{mL}$ ) at $1 \mathrm{mg} / \mathrm{mL}$ concentrations. Five different concentrations $(10-50 \mathrm{mg} / \mathrm{mL})$ were prepared by two-fold dilution method [41-43] and loaded into agar wells. Before incorporating the stock solution of test and reference compounds in to the agar wells, the agar plates were seeded with respective bacterial and fungal strains in a suitable concentration. The loaded petri plates were incubated at $37^{\circ} \mathrm{C}$ for $18-24 \mathrm{~h}$ and after incubation their MIC values were determined as Table- 2 .

The result showed that all the synthesized metal complexes showed good antimicrobial activities as listed in Table-2. Cobalt and nickel complex showed significant antimicrobial activities against S. aureus MTCC 3160 and S. aureus MTCC 25923 in comparison to both the standards, gentamycin and amphotericin-B with the highest mean zones of inhibition.

The antimicrobial activities of the synthesized molecules against S. aureus MTCC 3160 and S. aureus MTCC 25923 as antibacterial and C. albicans MTCC 227 and S. cereviscae MTCC 361 as antifungal in comparison to that of gentamycin and amphotericin-B.

\section{Conclusion}

In this article, copper(II), cobalt(II) and nickel(II) complexes with newly Schiff base ligand have been synthesized and characterized by different techniques like physico-chemically and spectroscopically. The analytical data are in a good

\begin{tabular}{|c|c|c|c|c|c|c|c|c|c|}
\hline \multirow{4}{*}{ Compounds } & \multirow{4}{*}{$\begin{array}{l}\text { Time } \\
\text { (h) }\end{array}$} & \multicolumn{6}{|c|}{$\begin{array}{l}\text { TABLE-2 } \\
\text { ANTIMICROBIAL ACTIVITY OF LIGAND AND THEIR METAL COMPLEXES }\end{array}$} & & \\
\hline & & \multicolumn{8}{|c|}{ Diameter of zone of inhibition (mm) } \\
\hline & & \multicolumn{2}{|c|}{ S. aureus MTCC 3160} & \multicolumn{2}{|c|}{ S. aureus MTCC 25923} & \multicolumn{2}{|c|}{ C. albicans MTCC 227} & \multicolumn{2}{|c|}{ S. cereviscae MTCC 361} \\
\hline & & $100 \mu \mathrm{g}$ & $50 \mu \mathrm{g}$ & $100 \mu \mathrm{g}$ & $50 \mu \mathrm{g}$ & $100 \mu \mathrm{g}$ & $50 \mu \mathrm{g}$ & $100 \mu \mathrm{g}$ & $50 \mu \mathrm{g}$ \\
\hline \multirow{2}{*}{ SBL } & 24 & 10 & 11 & 11 & 12 & 13 & 12 & 9 & 8 \\
\hline & 48 & 12 & 15 & 13 & 13 & 11 & 10 & 8 & 9 \\
\hline \multirow{2}{*}{ Co(II) complex } & 24 & 20 & 22 & 23 & 26 & 29 & 27 & 29 & 28 \\
\hline & 48 & 21 & 24 & 24 & 19 & 21 & 20 & 22 & 29 \\
\hline \multirow{2}{*}{$\mathrm{Ni}(\mathrm{II})$ complex } & 24 & 29 & 28 & 20 & 28 & 25 & 27 & 21 & 28 \\
\hline & 48 & - & - & - & - & 21 & 29 & 22 & 25 \\
\hline \multirow{2}{*}{$\mathrm{Cu}$ (II) complex } & 24 & - & - & - & - & 23 & 20 & 20 & 20 \\
\hline & 48 & 24 & 20 & 23 & 22 & 24 & 13 & 14 & 21 \\
\hline \multirow{2}{*}{ Gentamycin } & 24 & 32 & 34 & 32 & 34 & - & - & - & - \\
\hline & 48 & 32 & 34 & 32 & 34 & - & - & - & - \\
\hline \multirow{2}{*}{ Amphotericin-B } & 24 & - & - & - & - & 17 & 21 & 17 & 21 \\
\hline & 48 & - & - & - & - & 17 & 21 & 17 & 21 \\
\hline
\end{tabular}


agreement with geometrical structures of all the complexes. All the metal complexes exhibit significant biological activities and resultant cobalt and nickel complex were showed significant antimicrobial activities against $S$. aureus MTCC 3160 and $S$. aureus MTCC 25923 species.

\section{ACKNOWLEDGEMENTS}

The author is thankful to ACBR, New Delhi, India, for providing the spectral and analytical facilities.

\section{CONFLICT OF INTEREST}

The authors declare that there is no conflict of interests regarding the publication of this article.

\section{REFERENCES}

1. S. Kundu, A.K. Pramanik, A.S. Mondal and T.K. Mondal, J. Mol. Struct., 1116, 1 (2016);

https://doi.org/10.1016/j.molstruc.2016.03.013.

2. A.A. Abdel Aziz, A.N.M. Salem, M.A. Sayed and M.M. Aboaly, J. Mol. Struct., 1010, 130 (2012); https://doi.org/10.1016/j.molstruc.2011.11.043.

3. Z.L. You, H.L. Zhu and W.S. Liu, Z. Anorg. Allg. Chem., 630, 1617 (2004); https://doi.org/10.1002/zaac.200400125.

4. A. Golcu, M. Tumer, H. Demirelli, R.A. Wheatley, Inorg. Chim. Acta, 358, 1785 (2005); https://doi.org/10.1016/j.ica.2004.11.026.

5. S.K. Tadavi, A.A. Yadav and R.S. Bendre, J. Mol. Struct., 1152, 223 (2018);

https://doi.org/10.1016/j.molstruc.2017.09.112.

6. R.C. Maurya, P. Patel and S. Rajput, Inorg. Met., 33, 817 (2003); https://doi.org/10.1081/SIM-120021648.

7. U. Bohme and B. Gunther, Inorg. Chem. Commun., 10, 482 (2007); https://doi.org/10.1016/j.inoche.2007.01.008.

8. L.C. Felton and J.H. Brewer, Science, 105, 409 (1947); https://doi.org/10.1126/science.105.2729.409.

9. K. Naresh Kumar and R. Ramesh, Polyhedron, 24, 1885 (2005); https://doi.org/10.1016/j.poly.2005.05.020.

10. A.N. Kursunlu, E. Guler, F. Sevgi and B. Ozkalp, J. Mol. Struct., 1048, 476 (2013); https://doi.org/10.1016/j.molstruc.2013.06.017.

11. K.J. Kilpin, W. Henderson and B.K. Nicholson, Polyhedron, 26, 204 (2007); https://doi.org/10.1016/j.poly.2006.08.009.

12. K. Kumar, M. Kamboj, K. Jain and D.P. Singh, Spectrochim. Acta A Mol. Biomol. Spectrosc., 128, 243 (2014); https://doi.org/10.1016/j.saa.2014.02.128

13. S.A. Patil, V.H. Naik, A.D. Kulkarni and P.S. Badami, J. Sulfur Chem., 31, 109 (2010); https://doi.org/10.1080/17415991003668186.

14. A.D. Kulkarni, S.A. Patil and P.S. Badami, J. Sulfur Chem., 30, 145 (2009); https://doi.org/10.1080/17415990802663133.

15. S.K. Sridhar, S.N. Pandeya, J.P. Stables and A. Ramesh, Eur. J. Pharm. Sci., 16, 129 (2002); https://doi.org/10.1016/S0928-0987(02)00077-5.

16. S.N. Pandeya, P. Yogeeswari, D. Sriram, E. de Clercq, C. Pannecouque and M. Witvrouw, Chemotherapy, 45, 192 (1999); https://doi.org/10.1159/000007182.
17. D.P. Singh, V. Malik, K. Kumar, C. Sharma and K.R. Aneja, Spectrochim. Acta A Mol. Biomol. Spectrosc., 76, 45 (2010); https://doi.org/10.1016/j.saa.2010.02.044.

18. I. Ahmad and A.Z. Beg, J. Ethnopharmacol., 74, 113 (2001); https://doi.org/10.1016/S0378-8741(00)00335-4.

19. M.V. Andrews, J. Shaffer and D.C. McCain, J. Inorg. Nucl. Chem., 33, 3945 (1971); https://doi.org/10.1016/0022-1902(71)80301-9.

20. R. Pfragner and R.I. Freshney, Culture of Human Tumor Cells, John Wiley \& Sons (2004).

21. T.C. Birdsall, Altern. Med. Rev., 3, 271 (1998).

22. L.R. Rudnick, Lubricant Additives, Chemistry Applications, edn 2, CRC Press, Boca Raton (2009).

23. K. Buldurun, N. Turan, A. Savci and N. Çolak, J. Saudi Chem. Soc., 23, 205 (2019); https://doi.org/10.1016/j.jscs.2018.06.002.

24. H.S. Çalik, E. Ispir, S. Karabuga and M. Aslantas, J. Organomet. Chem., 801, 122 (2016); https://doi.org/10.1016/j.jorganchem.2015.10.028.

25. X. Dong, Y. Wang and Z. Qin, Acta Pharmacol. Sin., 30, 379 (2009); https://doi.org/10.1038/aps.2009.24.

26. P.A. Vigato and S. Tamburini, Coord. Chem. Rev., 248, 1717 (2004); https://doi.org/10.1016/j.cct.2003.09.003.

27. K. Shivakumar, P. Shashidhar, P. Vithal Reddy and M.B. Halli, J. Coord. Chem., 61, 2274 (2008); https://doi.org/10.1080/00958970801905239.

28. G.G. Mohamed, M.M. Omar and M.M. Hindy, Spectrochim. Acta A, Mol. Biomol. Spectrosc., 62, 1140 (2005); https://doi.org/10.1016/j.saa.2005.03.031.

29. K. Nakamoto and S.J. McCarthy, Spectroscopy \& Structure of Metal Chelate Compounds, John Wiley \& Sons: USA (1968).

30. A.B.P. Lever, Inorganic Electronic Spectroscopy, Elsevier: Amsterdam (1968).

31. B.N. Figgis, Introduction to Ligand Fields, edn 1, p. 263 (1966).

32. L.J. Bellamy, The Infrared Spectra of Complex Molecules, Chapman and Hall: London, edn 3 (1975).

33. P.K. Shama and S.N. Dubey, Indian J. Chem., 33A, 1113 (1994).

34. T. Ahamad, N. Nishat and S. Parveen, J. Coord. Chem., 61, 1963 (2008); https://doi.org/10.1080/00958970701795698.

35. I.T. Ahmed, Transition Met. Chem., 32, 674 (2007); https://doi.org/10.1007/s11243-007-0232-4.

36. J.C. Rasmussen, H. Toftlund, A.N. Nivorzhkin, J. Bourassa and P.C. Ford, Inorg. Chim. Acta, 251, 291 (1996); https://doi.org/10.1016/S0020-1693(96)05282-6.

37. M.C. Cardia, M. Begala, A. Delogu, E. Maccioni and A. Plumitallo, Il Pharmaco, 55, 93 (2000); https://doi.org/10.1016/S0014-827X(99)00124-X.

38. N. Turan and K. Buldurun, Eur. J. Chem., 9, 22 (2018); https://doi.org/10.5155/eurjchem.9.1.22-29.1671.

39. M. Sebastian, V. Arun, P.P. Robinson, A.A. Varghese, R. Abraham, E. Suresh and K.K.M. Yusuff, Polyhedron, 29, 3014 (2010); https://doi.org/10.1016/j.poly.2010.08.016.

40. H. Dugas and C. Penney, Bioorganic Chemistry, Springer: New York, pp. 435-448 (1981).

41. J.D. Margerum and L.J. Miller, Photochromism, Interscience-Wiley: New York, pp. 569-570 (1971).

42. W.J. Sawodny and M. Riederer, Angew. Chem. Int. Ed. Engl., 16, 859 (1977); https://doi.org/10.1002/anie.197708591.

43. R. Manikandan, P. Viswanathamurthi and M. Muthukumar, J. Mol. Biomol. Spectrosc., 83, 297 (2011); https://doi.org/10.1016/j.saa.2011.08.033. 